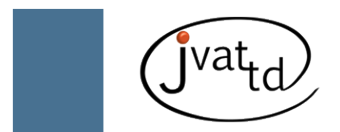

\title{
Immunophenotypic characterization of patients with American cutaneous leishmaniasis prior to and after treatment in Pernambuco, Brazil
}

Almeida AF (1), Castro MCAB (1), Oliveira AP (1), Souza MA (1), Pereira VRA (1)

(1) Department of Immunology, Aggeu Magalhães Research Center, Oswaldo Cruz Foundation, FIOCRUZ, Recife, Recife, Pernambuco State, Brazil.

\begin{abstract}
Leishmania infections induce a specific activation of host immunological response, particularly characterized by $T$ cell expansion. Studies indicate the importance of the balance between $C D 4^{+}$and $C D 8^{+}$ $T$ cells, in which the first ones would have their number reduced during the healing process. Meanwhile, $\mathrm{CD} 25^{+} \mathrm{T}$ cells have been associated with the suppression of the immune response. Since the immune response has an essential role in both healing and progression of diseases, this study aimed to identify the percentage of $\mathrm{CD}^{+}, \mathrm{CD}^{+}, \mathrm{CD}^{+}, \mathrm{CD}^{1} 6^{+}$and $\mathrm{CD} 25^{+} \mathrm{T}$ cells in the peripheral blood of patients afflicted with American cutaneous leishmaniasis ( $A C L)$ - before and after treatment - and healthy controls. Peripheral blood was collected and transferred to cytometry tubes containing monoclonal antibodies specific for cell surface markers CD3, CD4, CD8, CD16 e CD25. The immunophenotypic and morphometric parameters of cells were determined by flow cytometry and the results demonstrated a significant increase in the number of $\mathrm{T} \mathrm{CD} 8{ }^{+}$cells after treatment, suggesting a cytotoxic $\mathrm{T}$ cell response. An increase in $\mathrm{CD} 25^{+} \mathrm{T}$ cells in patients with active $A C L$ and after treatment was also observed, suggesting the participation of these cells in the modulation of the exacerbated effector response.
\end{abstract}

Key words: American tegumentary leishmaniasis, cellular immune response, flow cytometry, Leishmania (Viannia) braziliensis.

American cutaneous leishmaniasis (ACL) is an anthropozoonotic disease caused by protozoans of the genus Leishmania and transmitted to humans by the bite of Lutzomyia phlebotomines (1-5). Leishmania (Viannia) braziliensis is the causative agent of most cases of ACL in Brazil, especially Pernambuco (5-7). Clinical manifestations vary from localized cutaneous ulcers to mutilating mucocutaneous lesions, and depend on parasite species, vector, epidemiological characteristics, genetic constitution, and immunological conditions of the host $(4,7,8)$.

Infections by Leishmania lead to a specific activation of the host immune response (9). Studies indicate the importance of the balance between $\mathrm{T} \mathrm{CD}^{+}$and $\mathrm{CD}^{+}$cells, in which the first ones would have their proportion reduced during the healing process $(10,11)$. Meanwhile, natural killer (NK) cells participate by secreting IFN- $\gamma$, important for the differentiation of Th1 and Th2 responses by $\mathrm{CD} 4^{+} \mathrm{T}$ cells, and also through direct cytotoxic effect on parasitized macrophages (12). In the meantime, $\mathrm{CD} 25^{+} \mathrm{T}$ cells have been associated with the suppression of the immune response by effector T cells $(13,14)$.

In the present study, the proportions of $\mathrm{CD}^{+}, \mathrm{CD}^{+}, \mathrm{CD}^{+}, \mathrm{CD} 6^{+}$and $\mathrm{CD} 25^{+} \mathrm{T}$ cells in peripheral blood of patients with ACL prior to and after treatment were analyzed and compared with healthy individuals. Blood samples were obtained from ten patients with active ulcers and, then, six months after the end of therapy samples 
were collected from seven of them, and also from ten healthy controls living in non-endemic areas.

Ten patients with localized cutaneous lesions were studied. The following criteria were used for diagnosis: type of lesion and epidemiological data compatible with cutaneous leishmaniasis (CL); positive Montenegro skin test (MST); detection of Leishmania parasites in skin lesions by PCR; presence of Leishmania-specific immunoglobulin $G$ antibodies in serum samples detected by indirect immunofluorescence.

All the patients came from areas in which leishmaniasis is endemic in the state of Pernambuco, Brazil. They were treated with Glucantime $^{\circledast}$ (Sanofi-Aventis, USA) and were considered cured six months after their lesions had completely healed. All ten patients (five men and five women) had active leishmanial skin ulcers at the beginning of the study (Table 1).

The mean age of the patients was $25.25 \pm 9$ years. Seven patients had a single lesion and three had two to four lesions. MST was positive for all patients, with areas of induration ranging from 8 to $16 \mathrm{~mm}$ in diameter. The detection of Leishmania parasites by PCR was performed in six of the ten studied patients and it was positive for all of them. Immunofluorescence test was performed on samples from all patients and tested positive in $70 \%$ of them. In patients who tested negative by immunofluorescence, the detection of Leishmania parasites was accomplished by PCR and immune response through MST, which resulted positive in all of them, thus, confirming the diagnosis.

The percentages of studied cell populations were determined for all patients as the proportion of gated peripheral blood cells in the lymphocyte region, through flow cytometry graphs. Peripheral blood was collected in tubes containing EDTA and transferred to cytometry tubes containing monoclonal antibodies anti-CD3-Fitc (Miltenyi Biotec, USA), anti-CD4-Fitc (eBioscience, San Diego, CA, USA), anti-CD8-PE (eBioscience, USA), anti-CD16-PE (Caltag, USA) and antiCD25-APC (BD Pharmingen, San Jose, CA, USA). After homogenization in a vortex, the mixture was incubated for 40 minutes. Following that, the samples were submitted to erythrocyte lysis, followed by washes and centrifugations, with posterior resuspension in $400 \mu \mathrm{L}$ of $1 \%$ paraformaldehyde. The immunophenotypic and morphometric parameters of cells were determined by flow cytometry.

The results indicated a similar profile between

Table 1. Clinical, epidemiological and laboratory aspects of patients with American cutaneous leishmaniasis in the state of Pernambuco, Brazil

\begin{tabular}{c|c|c|c|c|c|c|c|c}
\hline Patient & Age & Gender & Area & Lesions & Lesion type & MST & PCR & IFI \\
\hline J.S.A & 32 & M & Moreno & 2 & Necrotic ulcer & $8 \mathrm{~mm}$ & + & + \\
\hline J.A.S & 26 & M & Moreno & 1 & Necrotic ulcer & $10 \mathrm{~mm}$ & $\mathrm{NI}$ & + \\
\hline C.D.S & 20 & M & Moreno & 1 & Necrotic ulcer & $10 \mathrm{~mm}$ & $\mathrm{NI}$ & + \\
\hline M. S. B. & 17 & F & Moreno & 1 & Necrotic ulcer & $8 \mathrm{~mm}$ & $\mathrm{NI}$ & + \\
\hline V. M. P. L. & 26 & F & Moreno & 1 & Necrotic ulcer & $15 \mathrm{~mm}$ & + & + \\
\hline D. A. S. & 15 & F & Moreno & 4 & Necrotic ulcer & $12 \mathrm{~mm}$ & + & + \\
\hline R. S. A. & 43 & F & Jaboatão dos & 2 & Necrotic ulcer & $16 \mathrm{~mm}$ & + & - \\
\hline A. M. O & 23 & M & Recife & 1 & Necrotic ulcer & $14 \mathrm{~mm}$ & + & - \\
\hline M. J.P. F. & NI & F & Moreno & 1 & Necrotic ulcer & $9 \mathrm{~mm}$ & + & - \\
\hline M. F. L. & NI & M & Moreno & 1 & Necrotic ulcer & $14 \mathrm{~mm}$ & $\mathrm{NI}$ & + \\
\hline
\end{tabular}

MST: Montenegro skin test; PCR: detection of the parasites by polymerase chain reaction; IFI: immunoglobulin detection by indirect immunofluorescence; +: positive; -: negative; NI: not informed. 
controls and patients prior and after treatment concerning CD3-, CD4- and CD16-positive populations (Table 2). Similar values were obtained by Autissier et al. (15) and Faria et al. (16) when evaluating healthy volunteers. Botelho et al. (12), studying the influence of treatment in phenotypic profile of patients, also did not notice significant differences in the $\mathrm{CD}^{+}, \mathrm{CD}^{+}$and $\mathrm{CD} 6^{+}$cells, between patients and controls. These results suggest that no harmful changes were induced by the treatment.

It was observed a significant increase in $\mathrm{T}$ $\mathrm{CD}^{+}$proportion in patients after treatment in comparison to controls $(\mathrm{p}=0.0250)$ and patients with active lesions $(\mathrm{p}=0.0418)$ (Table 2, Figure 1).

That reflected in the $\mathrm{CD} 4^{+} / \mathrm{CD} 8^{+}$ratio $(2.79 \pm$ 0.83 in controls; $3.22 \pm 1.18$ in patients with active lesions; $2.34 \pm 0.96$ in patients after treatment), which decreased in these patients, as shown in Figure 2. It is known that $\mathrm{CD}^{+} \mathrm{T}$ cells participate in the immune response by a cytolytic effect upon parasitized macrophages. $\mathrm{CD}^{+} \mathrm{T}$ cells have been associated with protection against Leishmania reinfection in murine models; however, the induction of these T-cell subsets in humans seems to be also related to the healing process (17). CD8 ${ }^{+} \mathrm{T}$ cells increased proportion after treatment suggests that the cytotoxic effect of these cells on parasitized cells may contribute to the elimination of the parasite.

Regarding the proportion of CD $25^{+} \mathrm{T}$ cells, a two-fold increase was observed between patients prior to treatment and controls $(\mathrm{p}=0.0068)$ and also between patients before and after treatment

Table 2. Proportion of T cells $\left(\mathrm{CD}^{+}\right)$, $\mathrm{T}$ helper cells $\left(C D 4^{+}\right)$, cytotoxic $T$ cells $\left(C D 8^{+}\right)$, natural killer cells $\left(\mathrm{CD} 16^{+}\right)$and regulatory $\mathrm{T}$ cells $\left(\mathrm{CD} 25^{+}\right)$in controls (CT), patients with active lesion (AT) and patients after chemotherapy (PT)

\begin{tabular}{c|c|c|c}
\hline & CT & AT & PT \\
\hline CD3 & $64.12 \pm 5.41$ & $61.38 \pm 3.91$ & $63.13 \pm 5.7$ \\
\hline CD4 & $38.17 \pm 4.78$ & $39.75 \pm 1.8$ & $42.09 \pm 5.9$ \\
\hline CD8 & $14.70 \pm 4.33$ & $13.35 \pm 4.27$ & $19.58 \pm 5.36 \#$ \\
\hline CD16 & $11.92 \pm 6.11$ & $12.02 \pm 3.72$ & $10.89 \pm 6.21$ \\
\hline CD25 & $3.22 \pm 1.6$ & $6.42 \pm 2.63 \#$ & $12.91 \pm 2.82 \#$ \\
\hline
\end{tabular}

$\# \mathrm{p}<0.05$ $(\mathrm{p}=0.0010) ; \mathrm{a}$ four-fold increase between patients after treatment and controls $(\mathrm{p}=0.0002)$ was also observed (Table 2, Figure 3). Belkaid et al. (14) explain that these cells regulate the function of local effector cells, which prevents efficient elimination of the parasite. In this model of response, parasite persistence, as a result of

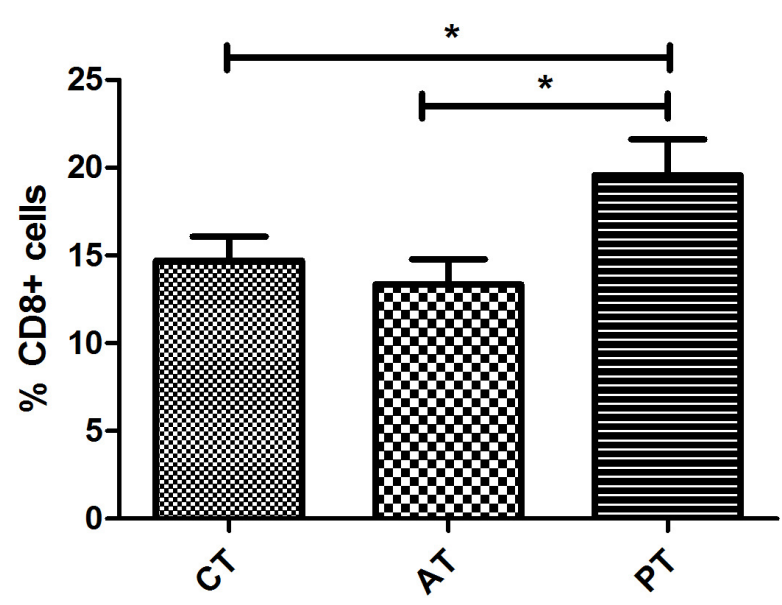

Figure 1. Proportion of cytotoxic T cells (CD8+) in the peripheral blood of controls (CT), patients with active lesion (AT), and patients after chemotherapy (PT). Differences between groups were considered significant when $\mathrm{p}<0.05$ and are indicated by asterisks $\left(^{*}\right)$.

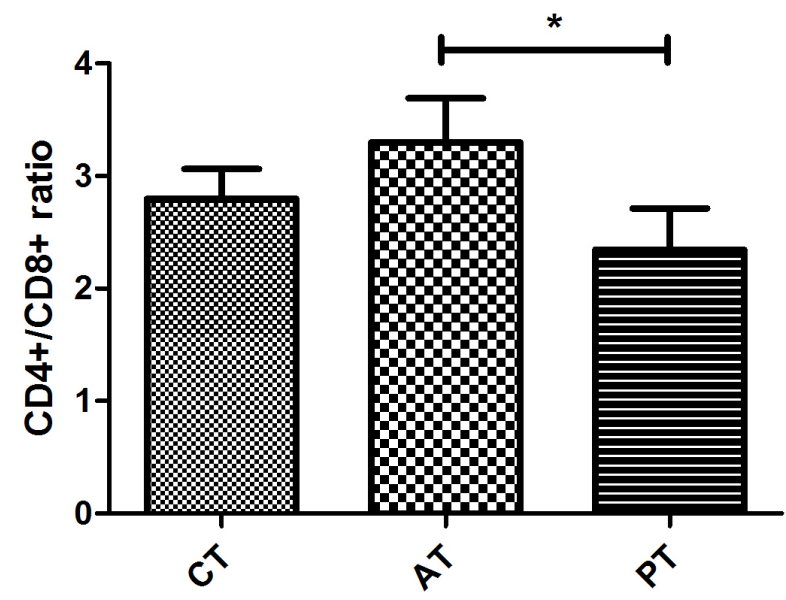

Figure 2. $\mathrm{CD} 4^{+} / \mathrm{CD} 8^{+}$ratio in the peripheral blood of controls (CT), patients with active lesion (AT), and patients after chemotherapy (PT). Differences between groups were considered significant when $\mathrm{p}<0.05$ and are indicated by asterisks $\left({ }^{*}\right)$. 


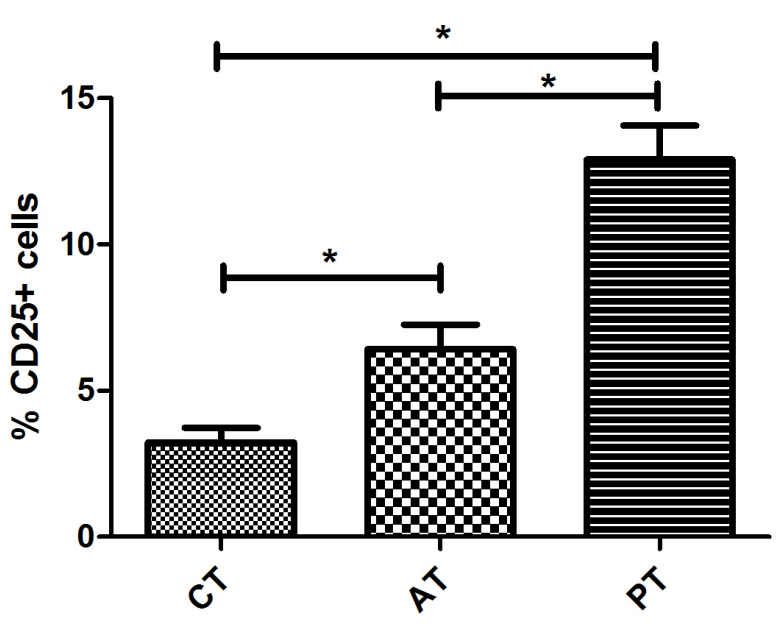

Figure 3. Proportion of regulatory T cells $\left(\mathrm{CD} 25^{+}\right)$in the peripheral blood of controls (CT), patients with active lesion (AT), and patients after chemotherapy (PT). Differences between groups were considered significant when $p<0.05$ and are indicated by asterisks $(*)$.

immune suppression by regulatory $\mathrm{T}$ cells, is necessary for the maintenance of protective immunity against the parasite.

After successful immunologic (or chemotherapeutic) control of Leishmania infection, a small number of parasites persisted, a situation that is associated with immunity to reinfection (known as "concomitant immunity"). Therefore, we believe that the immune response plays a fundamental role in the development of leishmaniasis and that CD8 ${ }^{+}$ $\mathrm{T}$ cells are associated with the healing process. Furthermore, we consider that the CD $25^{+} \mathrm{T}$ cell expansion, presented by patients, may be due the role of these cells in the modulation of an exacerbated response by effector $\mathrm{T}$ cells, and maintenance of a small number of parasites in the localized lesion as an antigenic stimulus to prevent reinfection.

Additional studies with more patients and markers are under development for a better comprehension of this process dynamics.

\section{ACKNOWLEDGEMENTS}

We are grateful to L. F. da Rocha for the technical assistance.

\section{COPYRIGHT}

(C) CEVAP 2011

\section{SUBMISSION STATUS}

Received: February 28, 2011.

Accepted: April 13, 2011.

Abstract published online: April 18, 2011.

Full paper published online: May 31, 2011.

\section{CONFLICTS OF INTEREST}

There is no conflict.

\section{FINANCIAL SOURCE}

Amanda F. Almeida received a Fiocruz/PIBIC research scholarship. Moreover, this study was supported by The National Council for Scientific and Technological Development (CNPq) and by the State of Pernambuco Research Foundation (FACEPE, process number APQ-0493-2.11/08).

\section{ETHICS COMMITTEE APPROVAL}

The present study was approved by the Aggeu Magalhães Research Center Ethics Committee (CAEE 0757.0.095.000-05). In addition, all studied subjects signed an informed consent form.

\section{CORRESPONDENCE TO}

VALÉRIA RÊGO ALVES PEREIRA, Departamento de Imunologia, Centro de Pesquisas Aggeu Magalhães, Av. Moraes Rego, s/n, Cidade Universitária, Recife, Pernambuco, 50670-420, Brasil. Phone: +55 812101 2631. Fax: +55 812101 2640. Email: valeriaph@gmail.com.

\section{REFERENCES}

1. Desjeux P. Leishmaniasis: current situation and new perspectives. Comp Immunol Microbiol Infect Dis. 2004;27(5):305-18.

2. Basano SA, Camargo LMA. Leishmaniose tegumentar americana: histórico, epidemiologia e perspectivas de controle. Rev Bras Epidemiol. 2004;7(3):328-37.

3. Ministério da Saúde. Manual de controle da leishmaniose tegumentar americana. 5. ed. Brasília: Ministério da Saúde; Fundação Nacional de Saúde; 2000. 62 p.

4. Gontijo B, Carvalho MLR. Leishmaniose tegumentar americana. Rev Soc Bras Med Trop. 2003;36(1):71-80.

5. Ministério da Saúde. Secretaria de Vigilância em Saúde. Manual de vigilância da leishmaniose tegumentar americana. 2. ed. Brasília: Ministério da Saúde; 2007. $180 \mathrm{p}$.

6. Brito ME, Andrade MS, Mendonça MG, Silva CJ, Almeida EL, Lima BS, et al. Species diversity of Leishmania (Viannia) parasites circulating in an endemic area for cutaneous leishmaniasis located in the Atlantic rainforest region of northeastern Brazil. 
Trop Med Int Health. 2009;14(10):1278-86.

7. Reis LC, Brito ME, Souza MA, Medeiros AC, Silva CJ, Luna CF, et al. Cellular immune response profile in patients with American tegumentary leishmaniasis prior and post chemotherapy treatment. J Clin Lab Anal. 2009;23(1):63-9.

8. de Moura TR, Novais FO, Oliveira F, Clarêncio J, Noronha A, Barral A, et al. Toward a novel experimental model of infection to study American cutaneous leishmaniasis caused by Leishmania braziliensis. Infect Immun. 2005;73(9):5827-34.

9. Da-Cruz AM, Bertho AL, Oliveira-Neto MP, Coutinho SG. Flow cytometric analysis of cellular infiltrate from American tegumentary leishmaniasis lesions. $\mathrm{Br} \mathrm{J}$ Dermatol. 2005;153(3):537-43.

10. Da-Cruz AM, Conceição-Silva F, Bertho AL, Coutinho SG. Leishmania-reactive CD4+ and CD8+ $\mathrm{T}$ cells associated with cure of human cutaneous leishmaniasis. Infect Immun. 1994;62(6):2614-8.

11. Coutinho SG, Da-Cruz AM, Bertho AL, Santiago MA, De-Luca P. Immunologic patterns associated with cure in human American cutaneous leishmaniasis. Braz J Med Biol Res. 1998;31(1):139-42.
12. Botelho AC, Mayrink W, Oliveira RC. Alterations in phenotypic profiles of peripheral blood cells from patients with human American cutaneous leishmaniasis following treatment with an antimonial drug and a vaccine. Acta Trop. 2009; 112(2):143-8.

13. Belkaid Y. Regulatory T cells and infection: a dangerous necessity. Nat Rev Immunol. 2007;7(11):875-88.

14. Belkaid Y. Role of Foxp3-positive regulatory T cells during infection. Eur J Immunol. 2008;38(4):901-37.

15. Autissier P, Soulas C, Burdo TH, Williams KC. Evaluation of a 12-color flow cytometry panel to study lymphocyte, monocyte, and dendritic cell subsets in humans. Cytometry A. 2010;77(5):410-9.

16. Faria AM, de Moraes SM, de Freitas LH, Speziali E, Soares TF, Figueiredo-Neves SP, et al. Variation rhythms of lymphocyte subsets during healthy aging. Neuroimmunomodulation. 2008;15(4-6):365-79.

17. Da-Cruz AM, Bittar R, Mattos M, Oliveira-Neto MP, Nogueira R, Pinho-Ribeiro V, et al. T-cell-mediated immune responses in patients with cutaneous or mucosal leishmaniasis: long-term evaluation after therapy. Clin Diagn Lab Immunol. 2002; 9(2):251-6. 